\title{
Long Journey Home
}

\section{Parezanović, Tijana. Terra Australis: Mitopoetika pripadanja. Alfa BK Univerzitet, 2019, str. 210.}

Australian literature, as one of the vital constituents of English-speaking literature, boasts a rich diversity of themes and style, as does the society and continent on which it is located. It is rooted in an ancient landscape, which carries some of the oldest cultural traditions, as well as a mixture of numerous cultural immigrants. Ever since Patrick White received the Nobel Prize for Literature in 1973, the literary critical public has turned its attention to the South, toward a distant and mystical land where contemporary writers who play with the aesthetic principles of the Western Circle have begun to emerge and remain loyal to Australia, attempting to understand and, at the same time, defining Australian culture - or a variety of its cultures.

Until recently, a small number of scholars from Serbia and the neighboring countries approached the study of Australian literature. Theoretical concern for the Australian literature never substantially advanced our understanding of this rich literary tradition, and the availability of critical literature on Australian literary production was limited. Therefore, a true refreshment for the critical public and readers of Australian literature was brought by an inspired theoretical and interpretive study written by Tijana Parezanović, entitled Terra Australis: Mitopoetika pripadanja (The Mythopoesis of Belonging), which was published (in Serbian) in 2019 by Alfa BK University.

Terra Australis: Mitpoetika pripadanja represents an innovative study that tackles mythological narratives, historical events and social phenomena, enriched with plentiful verses of prolific Australian poets. The book is divided into nine chapters focused on Australian poetry of the 20th century, written and published approximately between 1890 and 1970. The author states that the main issue that still occupies the attention of many Australian writers today is the question of origin or affiliation. It can, of course, be seen at different levels (and can also be rejected as invalid). At 
the most fundamental level of the personal, it comes down mainly to children's reflections on "who our parents are," while on a more general, collective level, it is reflected in the topic of togetherness, national feelings or the need to belong to the country as a geographical and metaphorical concept (9). Through the images of father, mother and, above all, child, in the Australian poetry of the twentieth century, many burning preoccupations of the society that develops along with literature are problematized, and these preoccupations are woven into the fabric of the story provided by this study.

At the beginning of this significant research, we are introduced to Andrew Barton Paterson (18641941) and Henry Lawson (1867-1922) who are largely responsible for the fact that we consider the work of their successors to be Australian. The thread leads toward the poetic and cultural productions related to the First World War, and is followed by Bernard O'Dowd (1866-1953) and Christopher Brennan (1870-1932), who play tricks with the European cultural heritage to a considerable extent. After these poets, the author introduces us to the pioneer of literary modernism in Australia, Kenneth Slessor (1901-1971) and the pioneer of postmodernism, the nonexistent poet Ern Malley (1918-1943), as well as with one of its creators, James McAuley (19171976). The story is closed with contemporary poets, whose work borders on the twenty-first century, as in the case of Judith Wright (1915-2000), or exceeds that limit, as in the case of David Malouf (b. 1934).

Although the book provides a solid insight into the 20th-century Australian poetry because it focuses on the authors whose lives and works have gained artistic and social recognition (we could perhaps venture to call them "canonical Australian poets"), this choice is, as the author points out, limited, primarily by space, and could include many other authors who equally deserve recognition, some of whom are briefly mentioned in the marginal space of footnotes (9).

With reference to the selected poets, Parezanović unveils a connection between the new mythical structures that appear in Australian culture toward the end of the nineteenth century and the settler colony's relationship with its imperial center - the connection which is manifested in the poetry of the given period through the metaphorical depictions of parenthood. As a settler colony undergoing a gradual process of separation from the parental (mostly maternal) figure of Great Britain, Australia can be imagined as a child. Indeed, the image of the child occupies one of the key places 
in the entire literary work of Australia: the child who most often disappears, the white child, lost, found or deceased, but also the black, stolen child. All literary children are a reflection of Australian national concerns and projections of future aspirations. The often neglected problem of parenthood is an integral part of these worries and desires, and the answers to the questions of motherhood and fatherhood are found in historical colonial frameworks (Mother Britain, Mother Australia), archetypal patterns of Western narratives and mythologies of ancient civilizations (mother Lilith, mother Earth, mother Medusa), as well as in metaphorical and metonymic representations (mother tongue).

Through the detailed analysis of the selected poetry, the author offers an insight into how the establishment of Australian literature runs in parallel with the establishment of the Australian state, and the assumption that Australia as a (would-be) nation-state is constructed as a myth, or on the basis of existing myths, is therefore not overly bold. The poetic shaping of the beginning (both literary and national, in the spatial and temporal sense) thus becomes one of the basic tasks of the artist due to the fact that the imagery of the mythological beginning/center, while different in the oeuvre of each poet, is still always recognizable as the actual beginning of the Creation of Australia (10).

The concept of journey, presented in all analyzed poetry in its various forms within this book - as border crossing in bush ballads, war poetry and Malley's poems, or travelling toward the source/center, which is identified as Europe in Brennan's case and as Australia in Slessor's, forms a syntagmatic interconnection between different poets thus pointing to a common cycle that they all belong to, moving from the bush ballads' nationalist propaganda toward internationalized experience in Kenneth Slessor's poetry and liberation of the settler colony's voice in the Ern Malley phenomenon. The very notions of the national(ist), international or (post)colonial literature point toward the significance of history, which is in the analyzed poems either mythologized and thus naturalized by reducing historical explorers and voyagers (Slessor) or bush pioneers and soldiers (ballads and The Anzac Book) to the ideal archetypal models, or described in Eliade's terms of the terror of history (particularly in Brennan's and Wright's poetry). The analysis has evidenced that Judith Wright's poetry shows a certain departure from previous models and structures. More precisely, she belongs to the same tradition of nature poetry as bush balladists do, and thus 
represents a proper conclusion to the here observed cycle of Australian poetry. However, the analytical parameters of the center and journey/quest are in her poems more closely related to the thus far suppressed and silenced experience of Australian Aborigines, whereby her poetry opens up new possibilities for potential readings of Australian literature, history, and experiences of living in this late discovered distant continent.

Parezanović further suggests that archetypal images, which sometimes imperceptibly cross from the work of one poet into the work of another, indicate the existence of a universal literary or human story on which Australian literature is based. An evocation of The Odyssey or biblical traditions reflects a story about a long journey home, about the quest for a place called home - the place to which one belongs. Therefore, Parezanović speaks - as the book's title has it - of the mythopoesis of belonging as an attempt to present this aspiration, the journey of longing for home, described through archetypal images of a child's relationship to parents, as a special Australian mythology, built through art worlds, while containing the possibility of building real worlds and communities. The Australian Odysseus, however, is a traveler who never returns home, to the shores of his homeland, because his home is moved forever ultra mare: if he is an immigrant, it is no longer England or any other country; if he is a native, it is no longer the same country as before the white settlement. Home is certainly Australia - but that Australia has millions of forms and represents a separate mental construct for each individual or each community. There is no single home or definitive answer to the question of where it is located. That at least is what the story told by Tijana Parezanović leads us to conclude.

We can agree with the author's conclusion at the end of this study, based on a quote from David Malouf, that only when one is sure that they belong to the environment, narrower or wider, to nature and space, but also to themselves above all things, can one speak of finding one's own path into culture. And the aspiration of belonging changes from person to person, from generation to generation. The only thing that matters is its intensity and effort that is invested in harmonizing inner life with the outside world. Such an effort ultimately brings peripheral Australian literature to one of the newly created centers in the pluricentric postcolonial world (199).

With her artistic understanding, expressed through lyrically evoked Serbian translations of the selected verse, Tijana Parezanović leads us to a new and distinctive dimension of understanding 
Australian literature that is read in one breath. Her aesthetically shaped thoughts manage to maintain the rigor of analytical and interpretive performances, and to theoretically base, analytically explain and meaningfully color her interpretations.

\section{(c) (i) (2)}

Creative Commons Attribution-NonCommercial-NoDerivatives 4.0 International License 